\title{
Det her føles helt rigtigt \\ En note i forbindelse med Dorthe Staunæs' tiltrædelsesforelæsning
}

og Danmarks Prdagogiske Universitetsskole har gjort sig et mægtigt scoop i deres nylige professoransættelse af Dorthe Staunæs. Her har vi en intellektuel kapacitet og energi af en hel særlig art, som præcist kropsliggør, hvad mange af os forventer os af eller håber på med en professortitel. Dorthe er på ingen måde ukendt af os som hænger ud i dansk kønsforskningssammenhænge, og det er dejligt, at vi med publiceringen af tiltrædelsesforelæsningen i dette nummer af KKF har anledning til at fejre hende og betydningen af hendes ansættelse.

Tiltrædelsesforelæsningen tilbyder os et indblik i et forskningsprogram og en vision. Begge er globalt inspireret og lokalt forankret. Det er et forskningsprogram med omdrejningspunkt i begrebet 'affekt' hvilket, som Dorthe selv bemærker, er 'mega-hot' indenfor kulturforskningen, men som trænger til indspark fra andre, traditionelt mere empirisk orienterede forskningsfelter såsom pædagogik, psykologi og ledelse, og fra an- 
dre teoretiske traditioner, såsom governmentalitetstænkningen. Med Dorthes efterhånden anseelige erfaringsbaggrund i teoretisk funderede empiriske analyser, hendes helt unikke kyndighed omkring udvikling af analysebegreber og analytiske strategier, og hendes evne til at integrere ofte adskilte fagdiscipliner, er der ingen tvivl om, at hun er den helt rigtige til at lede og inspirere disse indspark.

Som Dorthe selv påpeger $\mathrm{i}$ forelæsningen, så har den røde tråd i hendes forskningsinteresser og -projekter omhandlet menneskelige tilblivelsesprocesser, "hvorigennem mennesker skabes som tænkende, handlende, talende, interagerende, følende og lærende". Hendes subjektiveringsforskning - socio-kulturelt, konstruktionistisk og poststrukturalistisk inspireret - har altid haft øje for og på sociale kategorier, hvor hun i nogle projekter har skruet op for volumen på kategorien etnicitet, i andre på køn, og mere nyligt har gjort en betydelig indsats for at sammentænke sociale kategorier, og hvad de gør ved hinanden, når de leves i deres samtidighed. Hun har alene og sammen med andre udgivet vigtige og meget anvendelige artikler, der har som ambition at 'retoole' eller bearbejde begrebet intersektionalitet, som netop prøver at gribe ideen om levet samtidighed. Efter min mening er det særligt i den forstand, at Dorthes bidrag til både dansk og international kønsforskning er vigtigt og anseeligt. Køn kan ikke længere tænkes eller analyseres $\mathrm{i}$ isolation. Ej heller kan andre levede sociale kategorier meningsfuldt begrebsliggøres uden køn.

De seneste år har Dorthe tilføjet endnu en farve til sin teoretiske, analytiske og empiriske palet; en farve som kan tone de farver, hun allerede har i brug, men også en farve som er i stand til at få alting til at fremtræede på nye måder. Med den 'affektive vendings' fokus på stemninger, følelser og fornemmelser kan vores gamle analyser genlæses, men mere centralt er de nye spørgsmål som begrebet åbner op. Dorthes forelæsning fremviser smukt både disse spørgsmål og deres omfang, men hun giver os også indsigt i nogle af de nye og friske svar der tilbydes - de indsigter som arbejde med begrebet i uddannelses- og ledelsessammenhænge kan give os.

Hvad enten man nu er med på den affektive vending, og/eller de andre nye vendinger, der ligesom den tager afsæt i en interesse for det ikke-diskursive, så er der ingen tvivl om, at det er en ambitiøs, fremadrettet og nytænkende dagsorden som Dorthe her formulerer. Der er en smittende sitren og energi i den forelæsning, som for mig føles helt rigtig. Det bliver enormt spændende at følge, hvordan hun, sammen med ligesindede kolleger, fortsat vil væve forbindelserne til det forudgående arbejde og skubbe det nye program videre. Vi glæder os.

Eva Bendix Petersen, senior lecturer

School of Education

University of Newcastle 